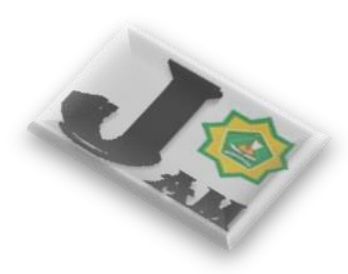

Al-Muqayyad

ISSN (print): 2715-3177| ISSN (online): 2614-8102

Program Studi Ekonomi Syariah, STAI Auliaurrasyidin Tembilahan

JournalHomepage: https://ejournal.stai-tbh.ac.id/index.php/al-muqayyad

\title{
Produksi Tempe Kedelai dalam Perspektif Ekonomi Islam
}

\author{
*Anna Nurhayati, , a, Seri Yanti Siagian ${ }^{2, b}$, Sai'in $^{3, c}$ \\ ${ }^{1,2,3)}$ STAI Auliaurrasyidin Tembilahan, Indragiri Hilir, Riau, Indonesia. \\ Email: anananurhayati.tbh2020@gmail.com;
}

\begin{tabular}{ll}
\hline DOI: & \multicolumn{1}{c}{ Cara Mensitasi Artikelini: } \\
$\begin{array}{ll}\text { https://doi.org/10.469 } \\
\text { 63/jam.v4i2.474 }\end{array}$ & $\begin{array}{l}\text { Nurhayati, N., Siagian, S. Y., \& Sai'in, S. (2021). Produksi tempe kedelai dalam } \\
\text { perspektif ekonomi Islam. AL-Muqayyad, 4(2), 134-143. } \\
\text { https://doi.org/10.46963/jam.v4i2.474 }\end{array}$
\end{tabular}

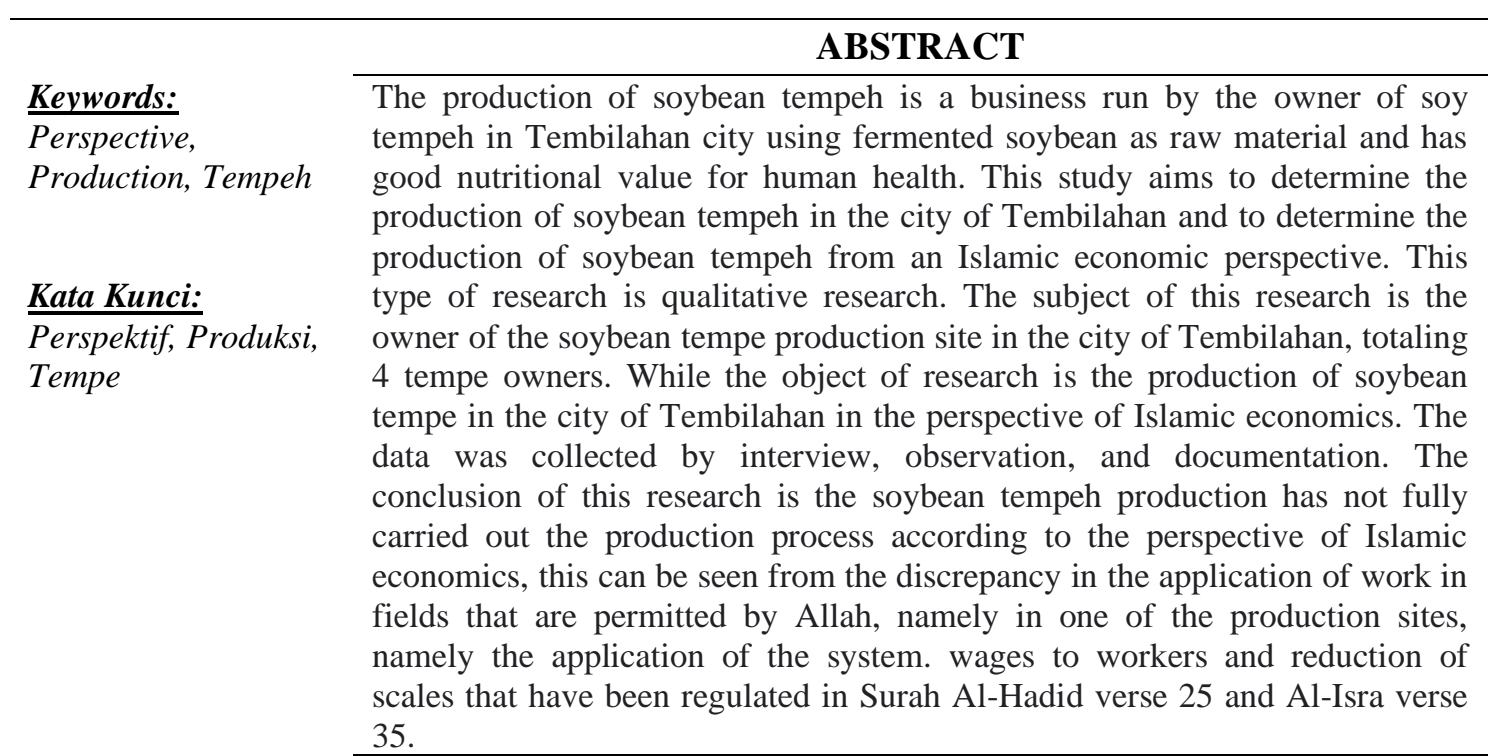

\section{Informasiartikel:}

Diterima:

01/12/2021

Direvisi:

Diterbitkan

30/12/2021

\section{*CorrespondingAuth \\ or}

ananurhayati.tbh2020

@ gmail.com

\section{ABSTRAK}

Produksi tempe kedelai merupakan usaha yang dijalankan oleh pemilik tempe kedelai di kota Tembilahan dengan bahan baku kedelai yang difermentasi dan memiliki nilai gizi yang baik bagi kesehatan manusia. Penelitian ini bertujuan untuk mengetahui produksi tempe kedelai di kota Tembilahan dan mengetahui produksi tempe kedelai dalam perspektif ekonomi Islam. Jenis penelitian ini adalah penelitian kualitatif. Penelitian ini yang menjadi subjek penelitian adalah pemilik tempat produksi tempe kedelai di kota Tembilahan yang berjumlah 4 pemilik tempe. Sedangkan objek penelitiannya adalah produksi tempe kedelai di kota Tembilahan dalam perspektif ekonomi Islam. Pengumpulan datanya dengan wawancara, observasi dan dokumentasi. Kesimpulan dari penelitian ini adalah produksi tempe kedelai belum sepenuhnya melakukan proses produksi menurut perspektif ekonomi Islam, hal ini dapat dilihat dari ketidaksesuaian dalam penerapan bekerja pada bidang yang dihalalkan Allah yaitu pada salah satu tempat produksi yaitu penerapan sistem pengupahan kepada pekerja dan pengurangan timbangan yang telah diatur dalam surah Al-Hadid ayat 25 dan Al-Isra ayat 35.

\section{PENDAHULUAN}

Menurut P3EI (2008) Produksi merupakan mata rantai konsumsi, yaitu menyediakan barang dan jasa yang merupakan kebutuhan konsumen. Produsen sebagaimana konsumen, bertujuan untuk memperoleh maslahah maksimum melalui 
aktivitasnya. Jadi, produsen dalam perspektif ekonomi Islam bukanlah seorang pemburu laba maksimal melainkan pemburu maslahah. Ekspresi maslahah dalam kegiatan produksi adalah keuntungan dan berkah sehingga produsen akan menentukan kombinasi antara berkah dan keuntungan yang memberikan maslahah maksimal.Oleh karena itu, tujuan prosen bukan hanya laba, maka pertimbangan produsen bukan semata pada hal yang bersifat sumber daya yang memiliki hubungan teknis dengan output, namun juga pertimbangan kandungan berkah (nonteknis) yang ada pada sumber daya maupun output.

Menurut Nana (2013: 351) Kegiatan memproduksi barang dan jasa merupakan salah satu kegiatan penting dalam mengelola perusahaan bisnis. R.W. Griffin memberikan defenisi bahwa produksi barang adalah memproduksi produk-produk berwujud, seperti radio, surat kabar, dan buku teks. Basu Swastha memberikan defenisi bahwa produksi adalah pengubahan bahan baku dari sumber-sumber menjadi hasil yang diinginkan oleh konsumen. Hasilnya dapat berupa barang atapun jasa.

Kegiatan produksi akan menciptakan kegunaan (utility), yaitu kemanapun produk memuaskan kegiatan manusia. Kegunaan (utility) yang diciptakan dalam produksi adalah kegunaan bentuk, kegunaan waktu, kegunaan tempat dan kegunaan kepemilikan.

Menurut Sukarno (2013: 249) Dalam Islam, prinsip fundamental yang harus diperhatikan dalam produksi adalah prinsip kesejahteraan ekonomi. Selanjutnya, Mannan menyatakan, "Dalam sistem produksi Islam, konsep kesejahteraan ekonomi digunakan dengan cara yang lebih luas. Konsep kesejahteraan Islam terdiri atas bertambahnya pendapatan yang diakibatkan oleh meningkatnya produksi dari barangbarang bermanfaat melalui pemanfaatan sumber daya secara maksimum, baik manusia maupun benda dan melalui ikut serta jumlah maksimum orang dalam proses produksi." Pernyataan ini menggambarkan aturan main produksi dalam Islam, yaitu produsen dapat mendapatkan laba yang diinginkan juga ada aturan bahwa barang yang diproduksi adalah barang yang bermanfaat dan sesuai dengan kebutuhan manusia sesuai dengan zaman.

Adapun aspek produksi yang berorientasi pada jangka panjang adalah paradigma berfikir yang didasarkan pada ajaran Islam, bahwa proses produksi dapat menjangkau makna yang lebih luas, tidak hanya pencapaian aspek yang bersifat rohani-keakhiratan. Senantiasa menegakkan shalat dan melakukan ibadah lainnya merupakan wujud dari nilai produktivitas yang dilakukan manusia dalam rangka memenuhi kebutuhan rohaninya. Seseorang yang melaksanakan shalat dengan benar, berarti telah melakukan aktivitas yang produktif yang akan membawa pada nilai lebih dalam mengarungi kehidupan didunia.

Dalam penelitian ini, peneliti mengambil judul tentang Produksi Tempe Kedelai di Kota Tembilahan. Tempe adalah salah satu produk fermentasi yang umumnya berbahan baku Kedelai yang di fermentasi dan mempunyai nilai gizi yang baik. Alasan 
peneliti memilih produksi tempe kedelai karena tempe merupakan makanan yang laris dijual dipasaran dan memiliki banyak manfaat bagi kesehatan tubuh manusia jadi aman untuk dikonsumsi. Dari informasi yang peneliti temui hasil wawancara singkat dengan pemilik tempe dan hasil survei pada tanggal 4 Januari 2021 Pukul 14.00, peneliti melihat usaha produksi tempe kedelai terletak di Jalan Prof M Yamin Sh, Jalan Pelita Jaya, Jalan Mandala, dan Jalan Lingkar 1. Usaha tempat produksi ini terletak menyatu dengan rumah akan tetapi tempat produksi Tempe ini memiliki ruangan tersendiri, ada yang disebelah rumah maupun dibelakang rumah pemilik. Tempat produksinya tidak terlalu besar, seukuran ruangan saja. Para pekerja nya sendiri bermacam-macam terdiri dari 1 sampai 4 orang. Dari informasi yang didapat, tempe hasil buatan ini dipasarkan di pasar, para pedagang keliling, rumah makan, dan pembeli yang membawa keluar daerah.

Berdasarkan studi pendahuluan yang peneliti lakukan pada tanggal 4 Januari 2021 Pukul 14.00 Wib, ditemukan masalah: dalam proses pembuatan tempe sering ditemukannya ampas didalam kacang kedelai, sehingga dalam melakukan proses pencucian kedelai harus benar-benar teliti dalam memilah ampas nya. Selain itu, sistem pengupahan juga belum merata yang diterapkan ditempat produksi tempe kedelai ini. masalah lain dalam proses produksi ini yaitu harga bahan baku kacang kedelai yang tidak stabil dan bisa berubah-ubah. Naiknya harga bahan baku akan berpengaruh pada pendapatan industri yang dijalankan. Masih adanya pedagang tempe kedelai yang mengalami kerugian, disebabkan naiknya harga bahan baku. Jika harga jual tempe dinaikkan dengan mengikuti naiknya harga bahan baku, maka permintaan konsumen akan menurun. Dalam hal ini proses penakaran ada timbangan juga harus mengikti harga pasar. Selanjutnya, dalam pengemasan tempe kedelai masih mengunakan cara tradisional dalam perekatan tempe kedelai, yakni menggunakan pelita yang berisi minyak tanah. Dan terakhir, dalam melakukan proses produksi, masalah yang ditemui yakni para pembuat tempe cenderung masih belum memahami tentang sistem produksi secara Islam, mereka hanya mengikuti kebiasaan dalam proes pembuatan tempe kedelai.

Berdasarkan latar belakang diatas, karna terlalu luasnya masalah maka peneliti akan menfokuskan penelitian ini pada "Norma dan Etika dalam Produksi Islam". Adapun pertanyaan artikel ini adalah bagaimana produksi tempe kedelai di Kota Tembilahan dan bagaimana produksi tempe kedelai menurut perspektif ekonomi Islam.

Pada umumnya, proses pembuatan tempe masih dilakukan secara tradisional (turun-terumurun) dalam skala industry kecil (Steinkraus, 1996; Sudarmadji et al, 1997; Astawan, 2013). Hal inilah yang menyebabkan banyak keragaman yang ditemukan dalam proses pembuatan tempe, baik antar daerah maupun antar produsen dalam satu daerah yang sama. Secara garis besar, tahapan-tahapan penting dalam pembuatan tempe, adalah: pembersihan biji kedelai, perebusan/pengukusan, pengupasan kulit, inokulasi kapang, pembungkusan, dan fermentasi. Proses fermentasi adalah tahap terpenting pada pembuatan tempe. Pada tahap ini, dilakukan pemeraman kedelai selama 
36- 48 jam menggunakan laru (kapang tempe). Kegiatan produksi dalam perspektif ekonomi Islam adalah terkait dengan manusia dan eksistensinya dalam aktivitas ekonomi, produksi merupakan kegiatan menciptakan kekayaan dengan pemanfaatan sumber alam oleh manusia. Berproduksi lazim diartikan menciptakan nilai barang atau menambah nilai terhadap sesuatu produk, barang dan jasa yang diproduksi itu haruslah hanya yang dibolehkan dan menguntungkan (yakni halal dan baik) menurut Islam (Mohammed Aslam Haneff, 2010).

Berdasarkan hal ini tujuan artikel ini adalah untuk mengetahui bagaimana produksi tempe di Kota Tembilahan dan untuk mengetahui bagaimana produksi tempe kedelai dalam perspektif ekonomi Islam. Kemudian manfaat artikel yang dapat diambil secara teoritis penelitian ini diharapkan dapat dijadikan bahan referensi yang dapat menambah wawasan pengetahuan bagi pembaca terutama tentang produksi tempe kedelai dalam perspektif ekonomi Islam dan dapat memberikan sumbangan bagi pengembangan konsep-konsep atau teori-teori tentang produksi tempe kedelai dalam perspektif ekonomi Islam. Secara praktis Sebagai bahan masukkan dan pertimbangan kepada para produsen tempe kedelai di Kota Tembilahan agar dapat melakukan produksi tempe kedelai yang sesuai dengan perspektif ekonomi Islam, sebagai acuan bagi masyarakat dalam melakukan produksi tempe kedelai di Kota Tembilahan yaitu dalam pemahaman tentang produksi dalam perspektif ekonomi Islam dan sebagai bahan kajian ilmu dan menambah referensi bagi peneliti selanjutnya dalam dunia ilmu pengetahuan yang berhubungan dengan produksi tempe kedelai dalam perspektif etika bisnis Islam.

\section{METODE}

Jenis penelitian yang digunakan peneliti adalah penelitian Kualitatif. Beni (2008: 121) metode penelitian ini muncul karena terjadi perubahan paradigma dalam memandang suatu realitas/fenomena/gejala. Dalam paradigma ini, realitas sosial dipandang seagai sesuatu yang holistik/utuh, kompleks, dinamis, dan penuh makna. Paradigma demikian disebut paradigma positivisme. Paradigma sebelumnya disebut paradigma positivisme, yang dalam memandang gejala, lebih bersifat tunggal, statis, dan konkret. Paradigma positivisme mengembangkan metode penelitian kualitatif, sedangkan paradigma positivisme mengembangkan metode kuantitatif.

Penelitian ini dilakukan di Jalan Prof M Yamin Sh, Jalan Pelita Jaya, Jalan Mandala dan Jalan Lingkar 1. Kabupaten Indragiri hilir Kecamatan Tembilahan. Waktu penelitian yaitu 3 (tiga) bulan sesudah dilaksanakannya seminar proposal. Terhitung mulai dari tangal 5 Apri 2021 sampai 5 Juni 2021.Subjek dalam penelitian ini yaitu pemilik produksi tempe kedelai di Kota Tembilahan. Objek penelitian ini adalah produksi tempe kedelai di Kota Tembilahan dalam perspektif ekonomi Islam.

Dalam penelitian ini yang dijadikan populasi adalah pemilik produksi Tempe kedelai di Kota Tembilahan yang berjumlah 20 pemilik tempat produksi. Sampel yang dipilih dalam Penelitian ini adalah tempat produksi Tempe kedelai. Penelitian

\section{Al-Muqayyad}

Vol 4 No 2 (2021) 
menggunakan purposive sampling yaitu peneliti mengandalkan penilaiannya sendiri ketika memilih anggota populasi untuk berpartisipasi dalam penelitian. Jadi peneliti mengambil sampel yang berjumlah 4 pemilik tempat produksi tempe kedelai.

Data primer dalam penelitian ini bersumber dari hasil wawancara dengan informan dengan menggunakan teknik purposive sampling, yakni memilih dan menentukan informan dengan pertimbangan dan tujuan tertentu dalam hal ini yaitu pemilik produksi tempe kedelai di Kota Tembilahan. Data sekunder diperoleh dari studi teoritis pustaka (library research) yakni pencarian data atau informasi dari buku-buku dan literature atau bahan bacaan lainnya yang sangat erat hubungannya dengan penelitian ini.

Teknik pengumpulan data yang digunakan dalam penelitian ini adalah wawancara, observasi, dan dokumentasi. Dalam hal ini wawancara dilakukan kepada pemilik tempat produksi tempe kedelai di Kota Tembilahan. Observasi yang diamati dalam penelitian ini adalah tempat produksi tempe kedelai di Kota Tembilahan. Dalam penelitian ini dokumentasi yang dicari adalah data sejarah usaha tempe, foto, gambar, dan data lainnya yang dianggap perlu dalam penelitian ini.

Analisis data merupakan usaha (proses) memilih, memilah, membuang, menggolongkan data untuk menjawab dua permasalahan pokok: tema apa yang dapat ditemukan pada data-data ini, dan seberapa jauh data-data ini dapat menyokong tema tersebut. Proses analisis data dimulai dengan menelaah seluruh data yang tersedia dari berbagai sumber. Data yang beranekaragam dibaca, dipelajari, ditelaah dan direduksi dengan jalan membuat rangkuman inti (abstraksi). Setelah melakukan abstraksi data disusun sesuai tema-tema. Kemudian dilanjutkan penafsiran sebagai hasil temuan sementara (jangan langsung percaya dengan hasil temuan). Temuan sementara tersebut ditelaah secara berulang-ulang hingga mampu menjadi sebuah teori substantif.Pada prinsipnya analisis data kualitatif dilakukan bersamaan dengan proses pengumpulan data. Teknik analisis yang dilakukan dengan menggunakan teknik analisis data yang dikemukakan oleh Miles dan Huberman dalam Basrowi dan Suwandi (2008: 209) mencangkup tiga kegiatan yang bersamaan: Reduksi data merupakan proses pemilihan, pemusatan perhatian, pengabstraksian dan pentransformasian data kasar dari lapangan. Proses ini berlangsung selama penelitian dilakukan, dari awal sampai akhir penelitian. Pada awal, misalnya: melalui kerangka konseptual, permasalahan, pendekatan pengumpulan data yang diperoleh. Selama pengumpulan data, misalnya membuat ringkasan, kode, mencari tema-tema, menulis memo, dan lain-lain. Selanjutnya penyajian data adalah sekumpulan informasi tersusun yang memberi kemungkinan untuk menarik kesimpulan dan pengambilan tindakan. Bentuk penyajiannya antara lain berupa teks naratif, matriks, grafik jaringan, dan bagan. Tujuannya adalah untuk memudahkan membaca dan menarik kesimpulan.Oleh karena itu, sajiannya harus tertata secara apik. Penyajian data juga merupakan bagian dari analisis, bahkan mencangkup pula reduksi data. Dalam proses ini peneliti mengelompokkan hal-hal yang serupa 
menjadi kategori atau kelompok satu, kelompok dua, kelompok tiga, dan seterusnya. Masing-masing kelompok tersebut menunjukkan tipologi yang ada sesuai dengan rumusan masalahnya. Terakhir, penarikan kesimpulan hanyalah sebagian dari suatu kegiatan dari konfigurasi yang utuh. Kesimpulan-kesimpulan juga diverifikasi selama penelitian berlangsung. Makna-makna yang muncul dari data harus selalu diuji kebenaran dan kesesuaiannya sehingga validitasnya terjamin. Dalam tahap ini, peneliti membuat rumusan proposisi yang terkait dengan prinsip logika, mengangkatnya sebagai temuan penelitian, kemudian dilanjutkan dengan mengkaji secara berulang-ulang terhadap data yang ada, pengelompokan data yang telah terbentuk, dan proposisi yang telah dirumuskan. Langkah selanjutnya yaitu melaporkan hasil penelitian lengkap, dengan 'temuan baru' yang berbeda dari temuan yang sudah ada.

\section{HASIL DAN PEMBAHASAN}

Dari hasil wawancara dan observasi kepada pemilik dan pekerja ditempat produksi tempe kedelai, Tempat produksi merupakan sebuah usaha keluarga yang didirikan oleh pemilik bersama anggota keluarganya. Tempat produksi tempe ini melakukan pembuatan tempe kedelai setiap hari karena dalam perhari ada langganan tetap yang memesan tempe kedelai ini, jadi dalam perharinya tempat produksi ini harus menyiapkan pesanan pelanggan. Bahan yang dibutuhkan dalam pembuatan tempe kedelai ini yang paling utama adalah kedelai dan ragi, kedelai sendiri dipesan di sebuah toko setiap hari dengan jumlah dan harga yang berbeda-beda setiap harinya. Ragi yang digunakan pun adalah ragi yang biasa dijual dipasaran, dan tidak ada bahan tambahan selain kedelai dan ragi. Pemilik mengatakan apabila hasil tempe kedelai ingin bagus maka dalam proses pencucian harus bersih terutama dari ampas kedelai yang terdapat dalam kacang kedelai, dalam pengolahannya pun tangan harus bersih dari berbagai macam minyak, seperti minyak wangi ataupun minyak goreng, hal ini adalah faktor ketidakberhasilan dalam pembuatan tempe kedelai.

Tempe kedelai hasil produksi ini dijual dipasar-pasar tradisional. Biasanya jika di pasar, pemilik langsung melakukan penjualan tempe kedelai ini karena keluarga pemilik selain menjual tempe juga menjual berbagi macam aneka sayuran dan lain-lain. Penjualan juga dilakukan oleh pedagang keliling yang mengambil tempe kedelai ini untuk dipasarkan keliling sambil menjual barang dagangan lainnya. Adanya langganan rumah makan seperti rumah makan ayam penyet yang memesan tempe perharinya untuk diolah menjadi tempe bacem. Selain itu, ada beberapa orang yang membeli yang dibawa keluar daerah dan juga untuk keperluan konsumsi. Beberapa dari Tempat produksi ini melakukan kerjasama, ada yang melakukan kerjasamanya dengan keluarganya dan pemilik yang enggan melakukan kerjasama karna pemilik hanya mengumpukan modal dan menikmati hasil penjualan nya sendiri.

Produksi dalam Islam telah diatur sesuai dengan ketetuan syara'. Produksi juga menciptakan berbagai macam manfaat dari barang hingga jasa, sehingga terdapat norma dan etika dalam produksi Islam terutama di Kota Tembilahan diantaranya:

\section{Al-Muqayyad}

Vol 4 No 2 (2021) 


\section{Ihsan dan Itqan (sungguh-sungguh) dalam berusaha}

Islam tidak hanya memerintahkan manusia untuk bekerja dan mengembangkan hasil usahanya (produktivitas), tetapi Islam memandang setiap usaha seseorang sebagai ibadah kepada Allah dan jihad di jalan Allah. M. Abdul Mun'in al-Jamal, dalam hal ini mengemukakan hal yang sama bahwa usaha dan peningkatan produktivitas dalam pandangan Islam adalah sebagai ibadah, bahkan aktivitas perekonomian ini dipandang semulia-mulianya nilai.

Islam telah menjelaskan bahwa setiap orang yang berusaha dipandang sebgai ibadah dan jihad di jalan Allah. Hal ini berarti tempat produksi telah melakukan sebuah usaha memproduksi tempe kedelai. Waktu yang telah diterapkan yakni pagi dan siang, sedangkan malam tidak adanya kegiatan membuat tempe kedelai, seperti yang telah dijelaskan dalam surah An-Naba' ayat 11:

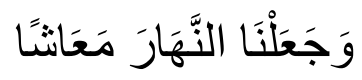

Artinya:"dan Kami jadikan siang untuk mencari penghidupan".

Selain berusaha dijalan Allah, tempat produksi juga mengambil keuntungan yang wajar, seperti yang telah djelaskan oleh Syaikh Wahbah Al-Zuhaili mengatakan sebaiknya seorang pebisnis tidak mengambil untung lebih dari sepertiga modalnya. Pendapat lain dari Ibnu 'Arabi mengatakan bahwa pengambilan keuntungan harus melihat etika pasar yaitu tidak boleh mengambil keuntungan terlalu besar. Pemilik produksi tempe kedelai umumnya mengambil keuntungan sesuai dari hasil tempe yang ia jual yaitu paling banyak setengah dari modal yang dikeluarkan oleh pemilik. Hal ini telah dijelaskan dalam surah An-Nisa ayat 29:

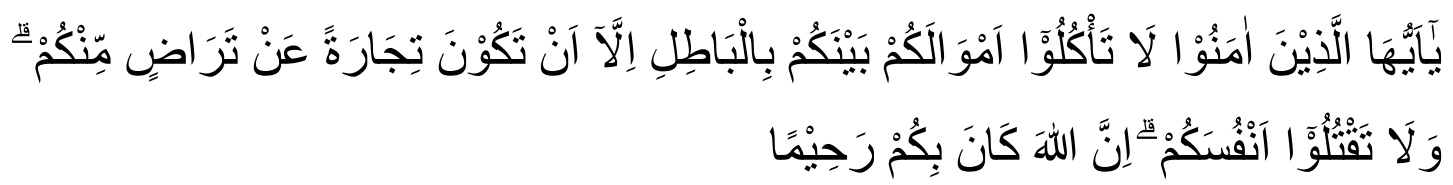

Artinya : "Wahai orang-orang yang beriman! Janganlah kamu saling memakan harta sesamamu dengan jalan yang batil (tidak benar), kecuali dalam perdagangan yang berlaku atas dasar suka sama suka di antara kamu. Dan janganlah kamu membunuh dirimu. Sungguh, Allah Maha Penyayang kepadamu.”

Selanjutnya, tanggung jawab juga di perlukan dalam proses produksi, hal ini sangat diperlukan karena dalam bekerja, apabila tidak adanya tanggung jawab antara pemilik dan pekerja tidak akan berjalan dengan semestinya. Tanggung jawab berarti bersunguh-sungguh dalam melakukan usahanya dan hal ini telah dilakukan oleh tempat produksi tempe kedelai yang telah menerapkan tanggung jawab dengan memproduksi tempe kedelai setiap hari atas dasar adanya pesanan dari pelanggan yang dijelaskan dalam surah Al-Azhab ayat 72: 
Produksi Tempe Kedelai dalam Perspektif Ekonomi Islam

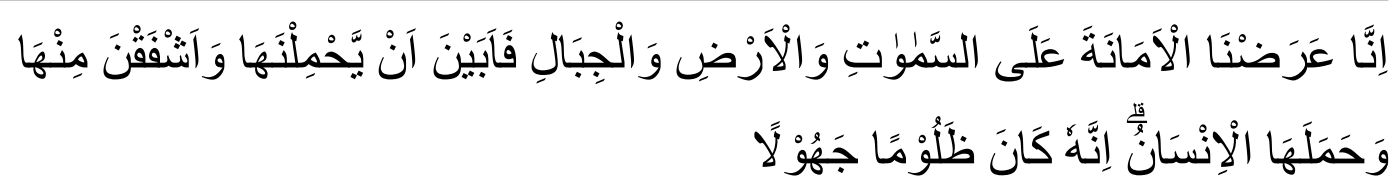

Artinya : "Sesungguhnya Kami telah menawarkan amanat kepada langit, bumi dan gunung-gunung; tetapi semuanya enggan untuk memikul amanat itu dan mereka khawatir tidak akan melaksanakannya (berat), lalu dipikullah amanat itu oleh manusia. Sungguh, manusia itu sangat zalim dan sangat bodoh."

\section{Iman, Taqwa, Maslahah, dan Istiqamah}

Iman, Taqwa, dan istiqamah merupakan pendorong yang sangat kuat untuk memperbesar produksi melalui kerja keras dengan baik, ikhlas, dan jujur dalam melakukan kegiatan produksi yang dibutuhkan untuk kepentingan umat, agama, dan dunia.

Telah dijelaskan bahwa memproduksi kebutuhan dalam Islam dilakukan untuk kepentingan umat manusia. Pada produksi tempe kedelai, proses produksi dilakukan setiap hari karena adanya langganan/pembeli yang membeli tempe kedelai ini setiap hari. Selain itu adanya manfaat (maslahah) dalam proses pembuatan tempe kedelai bagi kesehatan dan manfaat bagi tubuh manusia. selain itu, adanya usaha ini memberikan manfaat kepada masyarakat yang ingin belajar membuat tempe kedelai di tempat produksi karna tempat poduksi ini memperbolehkan siapa saja yang ingin belajar membuat tempe kedelai, artinya di tempat produksi ini memberikan manfaat/maslahah kepada orang lain seperti yang telah dijelaskan dalam surah Al-A'raf ayat 18:

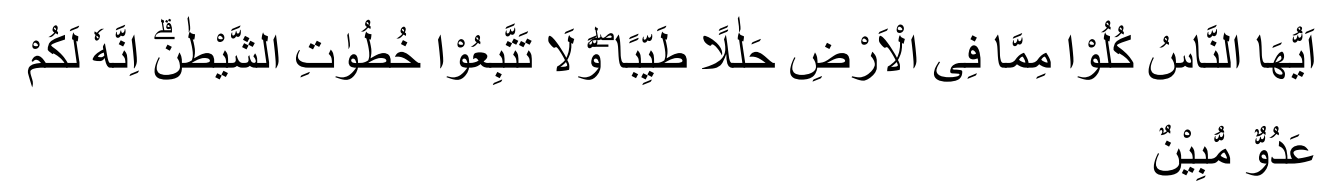

Artinya : "Wahai manusia! Makanlah dari (makanan) yang halal dan baik yang terdapat di bumi, dan janganlah kamu mengikuti langkah-langkah setan.Sungguh, setan itu musuh yang nyata bagimu."

\section{Bekerja pada Bidang yang Dihalalkan Allah}

Akhlak utama yang harus diperhatikan seseorang Muslim dalam bidang produksi secara pribadi maupun kolektif adalah bekerja pada bidang yang dihalalkan Allah. Oleh karena itu, setiap usaha yang mengandung unsur kezaliman dan mengambil hak orang lain dengan jalan yang batil, seperti mengurangi takaran dan timbangan dan sebagainnya, memperoleh sesuatu yang tidak diimbangi dengan kerja atau pengorbanan yang setimpal seperti riba dan sejenisnya, harta yang dihasilkan dari barang yang haram seperti khamar, atau bekerja di bidang perkerjaan yang tidak dibenarkan menurut syariat seperti kerja di bar atau diskotik diharamkan Islam.

\section{Al-Muqayyad}

Vol 4 No 2 (2021) 
Produksi tempe kedelai adalah sebuah usaha yang dihalalkan oleh Allah apabila mengikuti segala aturan yang telah ditetapkan dan janganlah ada unsur kezaliman dan mengambil hak orang lain. Dalam proses produksi tempe kedelai ini sistem upah yang diterapkan di 3 tempat telah menerapkan aturan pengupahan kepada semua pekerja sedangkan di 1 tempat pemilik hanya tertuju kepada satu orang pekerja saja, sedangkan yang lainnya tidak mendapatkan upah dengan alasan serumah, hal ini dalam aturan Islam tidak diperbolehkan karena pekerja tidak memperoleh apa-apa dari hasil kerjanya/tidak setimpal dengan hasil kerja yang dilakukanya, jadi disini terdapat ketidakadilan yang telah dijelaskan dalam Al-Hadid ayat 25:

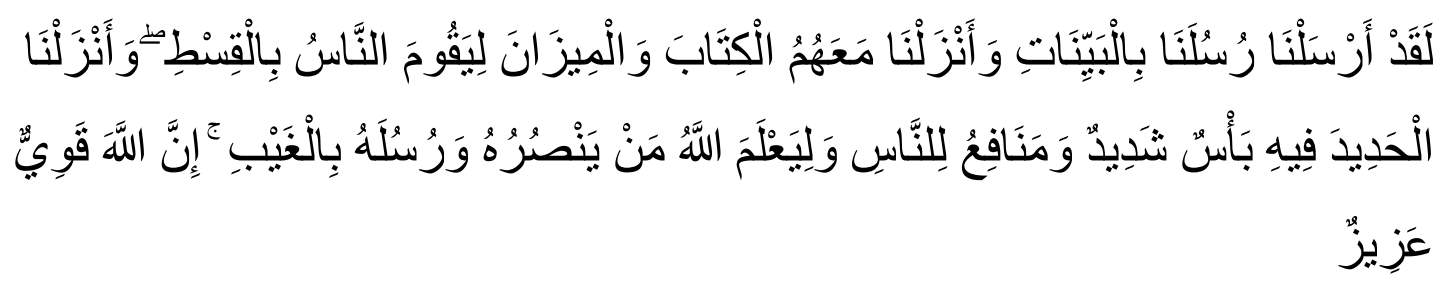

Artinya :"Sesunguhnya Kami telah mengutus Rasul-Rasul Kami dengan membawa bukti-bukti yang nyata dan telah Kami turunkan bersama mereka Al kitab da neraca (keadilan) supaya manusia dapat melaksanakan keadilan. Dan Kami ciptakan besi yang padanya terdapat keuatan yang hebat dan berbagai manfaat bagi manusia, (supaya mereka mempergunakan besi itu) dan supaya Allah mengetahui siapa yang menolong (agama) Nya dan Rasul-Rasul-Nya padahal Allah tidak dilihatnya. Sesungguhnya Allah Maha kuat lagi Maha Perkasa."

Selain itu, dalam proses penimbangan kedelai juga mengalami karena terdapatnya pengurangan takaran yang diakibatkan oleh harga kedelai yang tidak stabil dipasar. Jadi pemilik memutuskan untuk mengurangi kedelai dalam timbangan, padahal dalam Islam mengurangi takaran termasuk perbuatan zalim dan mengambil hak orang lain dengan cara yang bathil dan telah dijelaskan dalam surah Al-Isra' ayat 35:

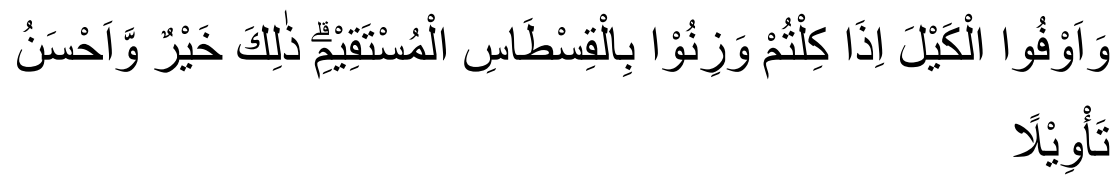

Artinya: "Dan sempurnakanlah takaran apabila kamu menakar, dan timbanglah dengan timbangan yang benar. Itulah yang lebih utama (bagimu) dan lebih baik akibatnya." 
Produksi Tempe Kedelai dalam Perspektif Ekonomi Islam

\section{SIMPULAN}

Berdasarkan hasil penelitian yang penulis lakukan dapat disimpulkan bahwa Produksi tempe kedelai melakukan proses produksi tempe kedelai ini setiap hari dengan bahan utama kedelai dan ragi. Kedelai yang dibutuhkan untuk membuat tempe berbedabeda setiap harinya. Tempe kedelai yang dihasilkan dari tempat produksi ini dijual di pasar-pasar tradisional dan langganan setiap harinya.

Produksi tempe kedelai dalam perspektif ekonomi Islam, masih belum sepenuhnya melakukan proses produksi menurut Islam. Hal ini dapat dilihat dari ketidaksesuaian dalam norma dan etika dalam produksi Islam dalam melakukan pengupahan kepada pekerja pada satu empat produksi dan penakaran pada timbangan yang tidak sesuai dengan ketentuan Al-Quran dalam surah Al-Hadid ayat 25 dan Al-Isra ayat 35 .

\section{REFERENSI}

Abdurrahman, Nana Herdiana. (2013). Manajemen Bisnis Syariah \& Kewirausahaan, Bandung: CV Pustaka Setia.

Basrowi dan Suwandi. (2008). Memahami Penelitian Kualitatif, Jakarta: PT Rijeka Cipta.

Departemen Agama RI, Al-Qur'an dan Terjemahan, Jakarta: Bintang Indonesia.

I Wayan Redi Aryanta. (2020). Manfaat tempe untuk kesehatan. Widya Kesehatan, 2(1), 44-50. https://doi.org/10.32795/widyakesehatan.v2i1.609

Pusat Pengkajian dan Pengembangan Ekonomi Islam. (2008). Ekonomi Islam, Jakarta: PT RajaGrafindo Persada.

Rozalinda. (2014). Ekonomi Islam, Jakarta: PT RajaGrafindo Persada.

Saebani, Beni Ahmad. (2008). Metode Penelitian, Bandung: CV Pustaka Setia.

Turmudi, M. (2017). Produksi Menurut Perspektif Ekonomi Islam. Jurnal Pemikiran Islam, 18(1), 37-56. http://dx.doi.org/10.30595/islamadina.v0i0.1528

Wibowo, Sukarno, \& Dedi Supriadi. (2013). Ekonomi Mikro Islam. Bandung: CV Pustaka Setia. 